\title{
"Invasão" à llha do Medo: o processo de implantação do turismo e a reação dos autóctones
}

\author{
Emilene Leite de Sousa
}

\begin{abstract}
resumo Este artigo visa refletir sobre o processo de implantação do turismo comunitário na Ilha do Medo, no Maranhão, e a reação dos autóctones frente a chegada dos "invasores", modo como eles definem os turistas. Trata também do diálogo que se estabelece entre os nativos e os planejadores de turismo enviados à Ilha do Medo. A reação dos autóctones à tentativa de transformação da Ilha em um novo atrativo turístico em São Luís demonstra a preocupação constante dos ilhéus em manter o modus vivendi local. As representaçóes dos nativos sobre os turistas estão respaldadas em dicotomias como: conservação x destruição, conhecido x desconhecido, moradores $\mathrm{x}$ invasores, segurança $\mathrm{x}$ perigo. Além de possibilitar uma reflexão sobre as relaçôes que se estabelecem entre nativos e turistas, a análise do processo de implantação do turismo nos permite compreender as redes de relaçóes sociais tecidas entre os planejadores de turismo, os nativos e o etnógrafo em campo.
\end{abstract}

palavras-chave Turismo. Antropologia. Autóctones. Turistas. Ilha do Medo.

\section{A Ilha do Medo}

A Ilha do Medo está localizada a noroeste da ilha de São Luís, distando $6.380 \mathrm{~m}$ da Praia Grande, em linha reta. Esta é mais uma das várias ilhas que compõem o arquipélago do Golfão Maranhense.

O acesso à ilha se dá por via marítima, por meio de embarcaçóes rústicas como jangadas, canoas, igarités e catamarãs. O ponto de saída é comumente a Ponta da Espera ou a rampa Campos Melo (Terminal Hidroviário de São Luís). O tempo de travessia de São Luís para a
Ilha do Medo é de dez minutos, se for feita da Ponta da Espera, e menos de trinta minutos, partindo do Terminal Hidroviário.

Seu litoral é composto por mangues, sizais, vegetação de praia além da vegetação arbustiva própria da área, como a palmeira de Babaçu. Há mata fechada, com inúmeros babaçuais que se propagam por toda a sua extensão.

Com relação à fauna, observamos espécies típicas de regióes de mangue, como insetos, peixes, moluscos, crustáceos (camarão, caranguejo, siri) e aves, como garças e guarás. A maioria dessas espécies serve de alimento e renda para a população da comunidade pesqueira. As principais atividades desenvolvidas pela comunidade são a pesca, a agricultura de subsistência e a extração de babaçu.

Náo existe infra-estrutura no local (água encanada, rede de esgoto e energia elétrica). A água provém do abastecimento de poços $\mathrm{e}$ pequenas fontes originadas das formaçóes rochosas da região.

De acordo com os relatos de alguns dos 36 moradores da Ilha do Medo, o local começou a ser habitado pela família de um senhor de 56 anos que já mora na ilha há mais de quarenta anos. Sua chegada à Ilha foi seguida da de uma outra família do município de São João Batista, interior do Maranhão, e estas duas se tornaram as famílias nucleares da região.

A Ilha do Medo está localizada no município de São Luís, porém, seu território pertence à União, sendo monitorado pela Marinha do Brasil. Por essa razão, todas as ocorrências extraordinárias são comunicadas à Marinha e, quando necessário, transformadas em boletins de ocorrência. 


\section{Exploraçóes: relaçóes de conflito na construção etnográfica}

Odeio as viagens e os exploradores. $E$ eis que me preparo para contar as minhas expediçóes

Claude Lévi-Strauss, 1996.

No início de 2006, recebi da Secretaria Municipal de Turismo/SETUR ${ }^{1}$ de São Luís, um convite para acompanhar uma equipe de profissionais das mais diversas áreas de conhecimento a uma ilha localizada a aproximadamente trinta minutos do litoral ludovicense, denominada Ilha do Medo, cuja realidade era desconhecida pela maioria dos moradores de São Luís e redondezas.

O objetivo da "exploração", como era chamada a nossa incursão à Ilha do Medo pelos turismólogos, pedagogos, assistentes sociais, geógrafos, topógrafos, arquitetos e biólogos que compunham a equipe, além de mim, era planejar o turismo com bases comunitárias ${ }^{2}$ na Ilha.

Como antropóloga, minha tarefa não era mais do que promover e mediar o diálogo entre os nativos e a equipe, na tradução de idiomas

1. A Secretaria de Turismo de São Luís/SETUR foi criada em dezembro de 2003 e, segundo seu estatuto, "tem como função promover o desenvolvimento do turismo sustentável no município de São Luís, favorecendo a valorização do patrimônio cultural e natural; a geração de trabalho e renda; e o fortalecimento da identidade e dos valores locais".

2. O turismo com bases comunitárias consiste num turismo planejado para que os nativos sejam os responsáveis diretos pelo entretenimento dos turistas no local, devendo, portanto, o projeto respeitar as regras locais, o modo de vida, a organizaçáo social do povo além de utilizar os próprios nativos como fornecedores dos mais diversos serviços como os de transporte, deslocamento, guia turístico etc. Em linhas gerais, quando há planejamento adequado e participaçáo da comunidade local durante o processo de preparação de uma região para o desenvolvimento de atividades turísticas falamos de turismo com bases comunitárias. culturais que faz do antropólogo, aos olhos dos hermeneutas, um intérprete. Como diz Laplantine: "a relação do etnógrafo que descreve um fenômeno social é não apenas uma relação significante, mas também uma relação que mobiliza uma atividade: a interpretaçâo de sentido" (Laplantine, 2004, p. 107).

Neste sentido, deveria explicar aos nativos a razáo da presença da SETUR na Ilha, buscando termos menos técnicos, mais informais para que a importância do turismo para a regiáo fosse entendida, bem como para vida deles mesmos e o "respeito" da SETUR pelos habitantes e seu modo de vida, razão da proposta de implantação do turismo com bases comunitárias.

Por esse motivo, durante a viagem, os turismólogos da equipe explicavam-me como o crescente fluxo de turistas na Ilha tinha chamado a atenção dos moradores, que procuraram a SETUR manifestando o desconforto e a insatisfaçáo dos habitantes em relação à nova situação.

Esta situação tornara-se ainda mais incômoda quando um folhetim local mandou uma de suas equipes à Ilha do Medo, que explorou a regiáo, conhecendo-a em todos os seus recantos, fotografou inúmeras paisagens e até mesmo casas e barquinhos sem a autorização de seus donos e publicou na primeira página, no início de 2006, a imagem de uma casa e um barquinho e outras paisagens da Ilha do Medo, oferecendo-a como novo destino turístico de São Luís ${ }^{3}$.

A SETUR, ao receber o morador que lá estivera reclamando dos "invasores" na Ilha, propôs uma visita ao local e explicou que seria possível um turismo planejado, que não ofereceria riscos

3. Em 20 de dezembro de 2006, um jornal de ampla circulação local divulgou, em sua versão on-line, a manchete Ilha do Medo: um potencial turistico inexplorado, informando sobre como chegar até o local, o que fazer lá, além de uma rápida descrição do histórico e do lugar seguida de algumas imagens. 
ao modo de vida dos habitantes e que seria supervisionado diretamente pela prefeitura e sua Secretaria de Turismo. Então, passou a planejar a implantação do turismo com bases comunitárias e me convidou para mediar esse primeiro encontro com os nativos. Assim, parti em busca do desconhecido.

Quando atracamos na Ilha do Medo, tendo que caminhar em meio à água e lamaçal até a praia, ficou à vista a falta de estrutura local de que se ressentiria a SETUR para transformar a Ilha em atrativo turístico.

A esta altura, eu estava curiosa em conhecer a Ilha, cuja história se mantinha como mistério e cuja distância cronometrada em trinta minutos de viagem de catamarã parecia um abismo entre suas praias lindas e o litoral ludovicense.

$\mathrm{E}$, naquele momento, com os pés na água, além de deslumbrada com a beleza do lugar que os meus olhos descobriam e que muitos caracterizariam sob "o mito da natureza intocada" eu estava atenta aos olhares dos moradores que de longe acompanhavam a nossa chegada.

O restante da manhã ensolarada que rapidamente ficou nebulosa, usamos para passar de casa em casa, apresentando-nos aos residentes e falando sobre o objetivo da "exploração", que era estudar o local e programar as construçóes e investimentos a serem feitos pela prefeitura para tornar a Ilha do Medo em mais um dos

4. A obra $O$ mito moderno da natureza intocada (Diegues, 1996) tece uma crítica à importação do modelo americano de criação de parques nacionais, pois em grande parte dos países da América do Sul e América Latina este modelo vem gerando conflitos sociais, causando a tragédia dos comunitários que são expulsos de seus territórios para a implantação de grandes projetos, quando não são completamente ignorados ou exclusos de participação nestes. A situação se agrava quando estas áreas naturais passam a servir como locais de turismo de aventura e verdadeiros paraísos da especulação imobiliária. atrativos do chamado turismo náutico ${ }^{5}$ que está despontando em São Luís.

Mas esta tarefa exigia dos profissionais ali reunidos um esforço contínuo em explicar e justificar a importância de que o turismo na Ilha fosse planejado. Os principais argumentos utilizados eram de que o turismo era inevitável, como a chegada dos primeiros "visitantes" já havia demonstrado, e que, diante disso, os habitantes do local deveriam buscar formas de lucrar com o turismo, e a prefeitura de São Luís estava disposta a ajudá-los, programando o turismo para que não houvesse danos aos ilhéus.

A partir daí, teve início uma discussão provocada a cada casa visitada e, mais tarde, na reunião geral com os residentes. Os habitantes da Ilha do Medo passaram a narrar a chegada dos "invasores", categoria utilizada por eles cada vez que se referiam aos turistas que apareciam esporadicamente ao local e, com o passar do tempo, com maior freqüência. A narrativa era marcada pela estranheza de ver o lugar onde os habitantes eram todos conhecidos e parentes - cuja melhor definição era "nossa casa”, como se referiam à Ilha - parecer aberto a pessoas estranhas, que passaram a freqüentálo sem serem apresentados aos moradores, sem cumprimentá-los, invadindo o seu cotidiano, instalando-se lá por dias, causando barulho, transtorno e deixando lixo por toda parte, até o momento em que partiam sem se despedir.

5. O turismo náutico caracteriza-se pela utilizaçáo de embarcações náuticas na atividade turística. Ele pode ser fluvial, lacustre, marítimo ou de represas. Pode ainda ser de dois tipos: o que faz uso de embarcações náuticas como finalidade de movimentação turística, quando a motivação do turista e a finalidade do deslocamento é a embarcação em si; e o que faz uso de embarcaçóes náuticas como meio de movimentação turistica, em que o transporte náutico é utilizado especialmente para fins de deslocamento, para o consumo de outros produtos ou segmentos turísticos, sendo este último o turismo náutico a ser desenvolvido na Ilha do Medo. 
Essas visitas, que eram esporádicas, tornaram-se, segundo os próprios moradores, cada vez mais sistemáticas, e em grupos cada vez maiores de "invasores". Sempre que se referiam aos turistas, eles utilizavam o termo "invasores", e a atividade turística era denominada "invasão", em frases como: "quando a invasão começou..." . ${ }^{6}$

Enquanto os turismólogos tentavam convencê-los de que poderiam estabelecer uma parceria com a SETUR, obter lucros e melhorar a qualidade de vida no local com bons empreendimentos turísticos e ganhando uma infra-estrutura oferecida pela prefeitura, os autóctones preocupavam-se com sua tranqüilidade, seu modo de vida e tradição. O medo presente no discurso deles era o medo da mudança repentina de um modus vivendi experienciado há quarenta anos por gerações.

Agindo como "colonizadora", a equipe $\mathrm{e}^{7} \mathrm{de}-$ monstrava total insensibilidade em relação aos moradores e aquilo que eles defendiam: seus

6. Lembramos que o turismo é definido como "um tipo específico de deslocamento praticado por um tipo específico de viajante que é o turista, diferenciado de outros tipos de viajantes por características como o objetivo da viagem, o tempo de permanência fora de casa e o estado de espírito" (Banducci Jr., 2005), o que torna indiferente o planejamento turístico do local visitado ou não. Ou seja, o turismo parece definido pela ação do turista e não como uma rede de relaçóes sociais culturalmente definidas. Comumente não se tem pensado o turismo pelo conjunto do sujeito que se desloca, a sociedade receptora, as relaçóes que se estabelecem com os nativos, elementos que constituiriam os chamados "encontros turísticos".

7. Vale ressaltar que a equipe de profissionais que participa das "exploraçôes" da SETUR não é formada pelo quadro permanente da própria Secretaria de Turismo, mas é constituída de convites a profissionais a cada vez que surge uma demanda a ser atendida. Como afirma Banducci Jr.: "os planejadores de turismo, ou seja, aqueles 'arquitetos' que constroem a oferta turística (em empresas privadas ou públicas) - o chamado 'produto turístico' para ser usufruído pelos turistas -, nutrem-se de vários ramos do conhecimento" (Banducci Jr., 2005, p. 09). valores, sua tradição, seu modo de vida. Prova disso é que, na medida em que falavam com os moradores em casa, como se esperassem deles algum tipo de apoio ou mesmo uma autorização, eu observava pelas janelas, de longe, topógrafos, biólogos, arquitetos e geógrafos atuarem lá fora, entre a flora e a fauna, rabiscando em pranchetas, apontando para os montes, medindo terrenos, procurando os pontos estratégicos para a construção de poços, trapiches, mirantes, restaurantes, pracinhas, pontos de descanso, sinalização de trilhas ecológicas e daí por diante.

Distraída e incomodada com o que observava lá fora, pela moldura da janela, fui discretamente abordada com um toque por uma das turismólogas sentada ao meu lado que, cansada de contra-argumentar com os moradores me indagou baixinho: "você não vai falar nada?", ao que eu respondi desconsertada: "estou achando o diálogo um pouco complicado", o que ela prontamente inferiu: "então! E não é por isso que você está aqui?”.

Naquele momento entendi a delicadeza do trabalho do antropólogo a que se referia $\mathrm{Da}$ Matta no seu "O ofício do etnólogo: ou como ter um anthropological blues" (DaMatta, 1978). O antropólogo é realmente convidado, não raras vezes - e nem sempre pelos nativos, acrescento - a exercer o papel de mediador em debates que não o agradam nem ética nem politicamente.

Mas esse não era o único problema, pois, se no fazer antropológico a relação etnógrafo/ nativo já nos parece tensa, o que dizer quando esta relação bipolar se transforma num triângulo que passa a envolver etnógrafo, turismólogos e nativos? Aliás, "a etnografia está relacionada à experiência das relaçóes de poder entre nativos e etnógrafos", como afirma Gonçalves:

Os textos etnográficos na verdade fazem parte, segundo James Clifford, de um sistema complexo de relaçóes; eles são pensados simultaneamente 
como condiçốes e efeitos de uma rede de relaçóes vividas por etnógrafos, nativos e outros personagens situados no contexto de situaçôes coloniais (Gonçalves, 2002, p. 10).

Neste caso, as relaçóes de poder se estendiam para além dos nativos e do etnógrafo aos planejadores do turismo. Diante disso, o exercício etnográfico a ser realizado por mim exigia a transformação constante dos profissionais do turismo, além dos nativos, em meu objeto de estudo. Esta experiência se torna ainda mais densa na medida em que eu ocupo um espaço na dialética dos olhares: dos turismólogos e dos nativos sobre os turistas; dos turismólogos sobre os nativos; e dos nativos sobre os turismólogos. Assim, construiu-se uma rede de relaçóes tensas e contraditórias, cujo emaranhado aprisionou a mim mesma. Minha principal tarefa seria então desvendá-la.

Através do olhar dos turismólogos, eu buscava enxergar os turistas sob outros aspectos e não apenas como intrusos, como comumente se faz na antropologia do turismo (Araújo, 2005). E esse olhar conflitava com o olhar dos nativos, que viam nos turistas o desejo de invadir e destruir aquilo que eles tanto protegiam: seu cotidiano.

Devo ressaltar que a minha experiência na Ilha do Medo foi marcada pela tentativa de implantação do turismo, que até agora não se efetivara. Diante disso, os aspectos expostos neste trabalho resultam muito mais da análise das relaçóes entre a equipe planejadora de turismo da SETUR de São Luís e os nativos da Ilha do que da relação estabelecida entre os nativos e os turistas, uma vez que a presença dos turistas na Ilha se dava esporadicamente, numa espécie de turismo avulso ou não planejado. Deste modo, as informaçóes contidas neste artigo sobre a relação entre nativos e turistas se fundamentam na análise do discurso dos nativos, consolidando-se numa espécie de estudo das representaçốes dos turistas pelos nativos da Ilha do Medo.

Cabe salientar que as representaçôes de um determinado grupo jamais se expressam como um conjunto harmonioso ou coeso, apresentando sempre alteraçóes a depender de quem fala e de onde está falando. Se, em se tratando de uma mesma categoria analítica, estas variaçôes nas representaçóes sobre um mesmo tema são evidentes, o que dizer da complexidade de relaçóes que envolvem os discursos diferenciados de homens, mulheres, jovens, adultos, idosos e crianças? As contradiçóes internas de um grupo são inúmeras e devem ser consideradas em sua complexidade.

Por essa razão, não concebo as representaçóes dos nativos ouvidos como predominantes ou hegemônicas no que se refere às impressóes dos nativos da Ilha do Medo sobre o turismo e os turistas. Entretanto, acredito que estas representaçóes são significativas para uma análise da reação destes nativos frente ao processo de implantação do turismo comunitário no local.

\section{A exploraçáo paralela: o medo como estratégia e o "livro sagrado" da comunidade}

Após o apelo da turismóloga para que eu tomasse partido na discussão, optei então por deixar a casa e buscar lá fora outros objetos e pessoas com quem pudesse interagir sem o peso da "colonização". Iniciei conversas paralelas em outros ambientes, menos formais como a cozinha, a calçada, a varanda, ou a própria praia, e busquei informaçôes distintas daquelas que "meus pares" pleiteavam.

Iniciei diálogos perguntando sobre famílias, parentesco e crianças, animais e plantaçóes, e até mesmo sobre a origem do nome dado à Ilha. E eis que quando menos esperamos os dados aparecem construindo um objeto que para 
mim veio praticamente ao meu encontro. Meu interesse, longe de ser a implantação do turismo com bases comunitárias ou a Ilha do Medo como um novo destino turístico, passou a ser as relaçôes que se estabeleciam entre os planejadores do turismo, nativos e turistas, sem deixar de fora aquela que se estabelecia comigo.

Minha saída do círculo de profissionais naquele instante, e mesmo a distância espacial que se colocava entre mim e eles, foi-me favorável. Um favorecimento que se veio somar ao meu silêncio ao longo de toda a discussão, quando eu parecia ser a única que, apesar de estar ali junto aos "colonizadores" - que, como os portugueses no Brasil, cruzaram os mares e chegaram em suas naus oferecendo melhores condiçóes de vida a todos - não argumentava a favor do turismo como necessário ou conseqüência inexorável da lei do progresso.

Se por um lado, como pesquisadora e "de fora”, eu parecia igual àqueles que insistiam em convencê-los sobre aquilo que os ilhéus menos desejavam, por outro, meu silêncio e interesse por assuntos diversos daqueles me aproximou dos moradores e me pôs em contato direto com as histórias do local.

$\mathrm{Na}$ minha "exploraçâo" paralela, ouvi narrativas sobre os mais estranhos mal-assombros, ocorrências sobrenaturais e divinas que fizeram da Ilha um lugar de histórias sinistras e sem explicaçôes, de mistério e perigo: a Ilha do Medo.

Descobri entâo, em meio às narrativas de mal-assombro, uma tentativa de assustar as pessoas que pensassem em se aproximar do local, mantendo distantes aqueles que não pertenciam à comunidade. Essas narrativas, com várias versões sobre o mesmo tema (o medo) iam desde o perigo do acesso ao local - caracterizado por um trecho denominado Boqueirão, de extrema profundidade e situado exatamente na circunferência em que estava a Ilha - até corpos de pessoas estranhas que aparecem em poços, pessoas que desaparecem da Ilha e gritos desesperados ouvidos pelas matas nas madrugadas. Todos esses acontecimentos tinham como vítimas estranhos e/ou forasteiros que apareciam no local e nunca alguém da comunidade.

O medo emergia entấo como um dispositivo através do qual os moradores tentavam manter os citadinos distantes, acreditando reduzir o número dos que se arriscavam a transpor o trecho que circundava a Ilha, chamado Boqueirão, descrito como extremamente profundo e perigoso, devendo ser ultrapassado somente por aqueles que conheciam bem o local, no caso, apenas os moradores da Ilha ${ }^{8}$.

Os nativos demonstravam muita satisfação e interesse em falar das condiçóes de vida no local; de como a prefeitura nunca se preocupara com eles; de como a Marinha era responsável pelo território mas não os ajudava; de como os habitantes compunham uma grande família, todos parentes, conhecidos, amigos; da vida tranqüila, a mesma tranqüilidade que trouxera à Ilha os primeiros habitantes do local e agora parecia ameaçada pelos "invasores", os intrusos.

Num desses depoimentos, uma senhora contou que seu marido, indo pescar pelas redondezas, "na hora que foi jogar a rede, quando

8. Em outubro de 1535, partiu de Portugal uma esquadra, comandada por Aires da Cunha, composta por dez embarcaçôes, com uma tripulação total de novecentos homens, fortemente armada e com 113 cavalos a bordo. Tinha a missão oficial de tomar posse da capitania Maranhão em nome de seu donatário, João de Barros. Em março de 1536, quando a esquadra chegava às costas do Maranhão, fortes chuvas e ventos assolavam a regiáo e, provavelmente devido a estas condiçóes climáticas adversas, a nau capitânia desapareceu nos baixios do Boqueiráo defronte a Ilha do Medo. Além desta, outras embarcaçôes da esquadra naufragaram próximas à Ilha do Medo. Já em 1864, gravemente enfermo, o poeta maranhense Gonçalves Dias é aconselhado em Paris à voltar ao Brasil, quando o seu navio, o Ville de Boulogne naufraga nas cotas do Maranhão, nas proximidades da Ilha do Medo, e todos se salvam, exceto Gonçalves Dias. 
deu fé, subiu um canudinho da água, quando ele pensa que não: um homem!". Segundo o seu depoimento e a descrição que fez do sujeito que emergiu da água, percebi que se tratava de um mergulhador, embora as águas turvas do litoral ludovicense não sejam atrativas à prática do mergulho. Esta situação fora esclarecida na busca de dados históricos sobre o local quando eu soube das naus que naufragaram no Boqueirão diante da Ilha, que passou a se constituir num dos trajetos dos caçadores de tesouros submersos no Brasil.

O mais interessante se deu quando, ao indagar sobre a história do local, uma das primeiras moradoras de lá me falou que já haviam escrito sobre a Ilha e que a história havia se transformado em livro. Curiosa, pedi que me deixasse ver a obra e indaguei sobre seu autor. Ela afirmou ser alguém que eles não conheciam e que o livro tinha sido encontrado na cidade de São Luís por um dos moradores que o comprara e trouxera. Insisti para que me mostrasse e, demonstrando zelo, ela me disse que só ela guardava a obra. E, como se tratasse de um documento sagrado, foi buscá-lo dentro de seu guarda-roupa, envolto de um plástico que deveria conservá-lo.

Então estendeu para mim uma obra em ótimo estado, editada numa série denominada Coleção Aventuras, composta de obras fictícias destinadas ao público adolescente, de autoria de um professor aposentado da universidade. Seu título, em letras grandes na capa, era $A$ Ilha do Medo, escrito sobre a pintura de uma praia e um barquinho diante de uma palmeira, semelhante a dezenas de imagens que eu havia visto naquela manhã na própria Ilha.

Não pude esconder a minha surpresa ao descobrir que o título do livro era uma coincidência e que não se referia à Ilha. Ainda assim, sem se dar conta da minha frustração, minha informante me mostrava empolgada muitas ilustraçôes da parte interna da obra como sendo retratos de sua própria "casa", como se referiam à Ilha.

Pensei de imediato que os ilhéus em sua maioria não soubessem ler, razão da confusão que transformou um livro de aventuras e ficção escrito para adolescentes no documento sagrado que narraria a história do local onde habitam. Mais tarde, descobri que quase todos na comunidade são alfabetizados, mas não têm o hábito da leitura e mesmo os que iniciaram a leitura da obra, tomaram para si e para sua Ilha a história criada para o entretenimento juvenil.

No meio da tarde chuvosa daquele primeiro dia de "exploração", guiados por um morador, seguimos para a construção da chamada trilha ecológica para que pudéssemos conhecer o outro lado da Ilha e vê-la do alto, no local onde deve ser construído o mirante, e o mais importante, estabelecer os chamados pontos de descanso ${ }^{9}$ das trilhas ecológicas. Embora minha presença não fosse necessária, resolvi acompanhá-los nesse trajeto, mais pela aventura do passeio do que pela busca de informaçóes.

Como nos ensinou Malinowski (1978), o antropólogo deve estar sempre atento, pois as informaçôes mais importantes nos são fornecidas nos momentos mais inesperados ou inoportunos. E, durante o trajeto, ouvimos do guia as histórias de perigo e assombração que povoavam a memória e a imaginação de todos no local. Passamos pelo poço misterioso onde

9. Dentre outras técnicas adotadas pela turismologia chamou-me a atenção a que é utilizada para a definição dos chamados pontos de descanso, que consistem em pontos de parada a serem arquitetados ao longo do trajeto da trilha ecológica, que devem conter mesinhas e banquinhos para o descanso dos turistas. Com esse fim, a equipe caminha até que um membro determinado previamente por eles sinta-se cansado, e cada parada feita por esse membro da equipe pressupóe um local importante para a construçáo de um ponto de descanso. 
o corpo de um estranho surgira, e que, por essa razão, perdeu por completo a sua utilidade, tendo ficado "isolado".

Conhecemos o farol pichado, mistura de rural e urbano, com sua grade destruída demonstrando que fora forçado para a entrada de alguém. Conservação e destruição colocavamse desde já como elementos da dicotomia que caracterizava e distinguia os nativos dos náonativos.

Os profissionais da equipe deixaram a Ilha naquele fim de dia prometendo para o mais breve possível a visita de médicos, dentistas e mais uma gama de profissionais da saúde que deveria cuidar de todos, o que, até este fim de 2006, não se realizara.

Além disso, a partida dessa equipe, depois de um dia de relaçôes conflitantes, instigava em mim mais uma dúvida: quem eram os "invasores" de fato? Além da certeza de que os invasores não eram necessariamente, ou não apenas, os turistas, restou-me também a clareza de que minha experiência etnográfica germinava e

se configurava como um campo articulado pelas tensōes, ambigüidades e indeterminações próprias do sistema de relaçóes do qual faz parte (Gonçalves, 2002, p. 10).

Por fim, reflito sobre o convite que me fora feito pela SETUR para participar desta "exploração". Não acredito que esse convite revele algum conhecimento por parte da Secretaria em relação ao trabalho do antropólogo ou sobre a reconhecida importância da presença de um antropólogo num primeiro contato com os autóctones, apesar de o conflito entre nativos e turistas estar na base de grande parte dos estudos sobre o turismo hoje. Como constatei mais tarde, o convite deveria mesmo ser pró-forma, para dar sustentação ao projeto a ser encaminhado à prefeitura de São Luís para transformar a Ilha do Medo num novo destino turístico. $\mathrm{O}$ intuito era de ter uma equipe o mais diversificada possível no que diz respeito à formação profissional de seus membros.

$\mathrm{Na}$ incômoda viagem de volta a São Luís, marcada por uma maré agitada e muitos sacolejos do catamará, os integrantes da equipe de planejamento, incrédulos, demonstravam indignação diante da "resistência" dos ilhéus à implantação do turismo. Falavam da necessidade de um trabalho de sensibilizaçáo e conscientização para que a população soubesse o que exatamente ganharia com o turismo e da importância da interação com os "de fora", "os visitantes que eles chamam insistentemente de invasores". Deste modo, diziam que existia no local "duas ilhas dentro de uma mesma ilha", referindo-se ao isolamento a que se submetiam os ilhéus que se recusavam a aceitar os "visitantes".

Durante esta conversa, uma turismóloga me falava do desejo de que fosse estabelecida uma parceria entre SETUR e Ilha do Medo, e eu pensava que entender a lógica do Outro parecia o caminho viável para o estabelecimento desta parceria. Esse deveria ser o esforço a ser feito pelos planejadores do turismo.

Além disso, perguntava-me como seria possível transformar os "invasores" (para os ilhéus) em "visitantes" (para a SETUR)? Acredito que o visitante seja sempre desejado, convidado, esperado. Ao contrário, "invasão" é o termo que parece melhor definir o ponto de vista dos ilhéus. Se por um lado, como me disse um informante turismólogo, "o turismo trabalha para que o visitante se sinta em casa", quando o turista se comporta como se estivesse em casa, sua conduta parece um desrespeito à casa do nativo, pois o turista se comporta como se vigorassem no lugar as leis e regras de sua própria casa e não um modo de vida diferenciado e que deve ser respeitado. 


\section{A Ilha do Medo e o medo do turismo: sobre o "não fale com estranhos"}

\author{
Viajar! Perder o pais! \\ Tornar-se outro constantemente \\ (Fernando Pessoa)
}

O turismo constitui um fenômeno social uma vez que implica no deslocamento de inúmeras pessoas que passam a ser habitantes temporários de locais nos quais não residem, ocasionando impactos na sociedade receptora.

A perspectiva antropológica do turismo define o turismo como um facto social total e também como um processo social, económico e cultural no qual participam diversos agêntes sociais: a política turística, a legislação turística, as agências de viagens, a publicidade, o turista, o anfitriāo, os profissionais do turismo, etc. Todos eles dotam ao turismo de sentidos geralmente múltiplos e complexos. Aos seus sentidos recreativo, educativo, económico e integrativo é preciso somar o social -ex.: contacto entre locais e turistas -, e o político. Estes sentidos sáo polisémicos, e podem predominar uns sobre os outros de acordo com os casos particulares, mas em linhas gerais o turismo está associado à sociedade consumista na qual estamos a viver, e na qual afirmamos a distinção social através do consumo (Perez, 2003, p. 233).

Com o contato entre culturas distintas, tem-se ampliado a vivência da alteridade, e como todo exercício de alteridade, a relação entre turista e anfitriăo (voluntário ou involuntário) tem sido dialética e muitas vezes conflituosa, tanto quanto as opiniōes e os estudos sobre o turismo realizados por diferentes áreas de saber, como a antropologia, a turismologia, a economia, a geografia etc.

$\mathrm{Na}$ antropologia, em especial, o incômodo se deu por conta do interesse dessa ciência em estudar os impactos sócio-culturais do turismo sobre a cultura local, com os processos de aculturação, endoculturação e as transformaçóes ocorridas no modus vivendi.

Se alguns resultados causaram um mal-estar à turismologia ou mais especificamente ao trade turístico, internamente, a própria antropologia passou a discutir questóes de identidade cultural, etnicidade, autenticidade, encenação cultural ou cultura inventada.

Para alguns antropólogos, haveria um resgate cultural promovido pela própria encenação da cultura para os turistas; para outros, a cultura se revelaria pelo artifício, mecanismo de atraçáo de novos públicos garantindo a venda do produto turístico.

O mais importante é que parece despontar aí um confronto de identidades conferidas pelo turista, pela mídia e pelos nativos. E como toda identidade é uma "identidade narrada" (Hall, 2005), a identidade do local passa a ser a soma de todas essas representaçôes dos sinais diacríticos em jogo. De acordo com Banducci Jr.:

$\mathrm{O}$ contato entre turistas e residentes, entre a cultura do turista e a cultura do residente, desencadeia um processo pleno de contradiçóes, tensōes e questionamentos, mas que, sincrônica ou diacronicamente, provoca o fortalecimento da identidade e da cultura dos indivíduos e da sociedade receptora e, muitas vezes, o fortalecimento do próprio turista que, na alteridade, se redescobre (Banducci Jr., 2005, p. 19).

O problema que se coloca desde já é o da relação entre nativos e não-nativos, ou os estabelecidos e os outsiders, fazendo uso das categorias de análise de Norbert Elias (2000). Utilizo-me aqui das categorias analíticas de Elias com alguma ressalva, visto que no seu estudo clássico sobre Winston Parva a preocupação do autor é com as relaçôes que se estabelecem entre os residentes antigos de um bairro da comunidade e 
os novos moradores do local. Na Ilha do Medo, as categorias de Elias nos permitem pensar as relaçôes estabelecidas entre nativos que, embora não possuam a propriedade da terra, consideram-se estabelecidos, e os turistas que, por sua situação de passagem, são outsiders.

Os residentes que lá estáo há mais de quarenta anos foram os primeiros a chegar ao local, pessoas advindas de municípios no interior do Maranhão e de bairros periféricos de São Luís, mulheres de cidades do interior que se casaram com alguns desses ludovicenses e acompanharam seus maridos na mudança para a Ilha do Medo.

Essa relação entre aqueles que habitam o local e foram os primeiros a chegar e os "de fora" colocam os primeiros em situação privilegiada, dando origem a um grupo coeso, cuja coesão é garantida pela identificação existente entre seus membros, que se diferem daqueles que freqüentam a Ilha em busca de diversão: os estranhos, os de fora, os outsiders.

Se sob determinados aspectos, os nativos ocupam posiçôes privilegiadas - especialmente pelo fato de serem os estabelecidos - noutros aspectos a relação de poder que se estabelece entre turistas e nativos, geralmente privilegia os turistas, como demonstrado na análise de Nash (1996).

Segundo este autor, as relaçóes entre os turistas e os nativos são marcadas pela disparidade de poder, considerando-se suas diferentes estruturas sociais. Assim, os turistas não esperariam adaptar-se para se envolver na vida da comunidade, fardo que acabaria caindo sobre os habitantes do local, um preço a ser pago por receberem forasteiros na comunidade.

A fronteira entre os habitantes do local e os forasteiros se estabelece por meio dos chamados sistemas classificatórios, responsáveis por aplicar princípios de diferença a uma população de tal forma que seja capaz de dividi-la em ao menos dois grupos opostos: nós/eles, eu/outro. Os sistemas de classificação operam na ordenação do social, produzindo diferença e garantindo, por meio das oposiçôes binárias, a construção das identidades. Ademais, a sociedade separa funcional e territorialmente tudo e todos (Bauman, 1998).

Assim, a ordem social é mantida por meio das oposiçóes binárias, tais como a divisão entre insiders e outsiders, com fins de estabelecer uma espécie de controle social. A produção da identidade do nativo tem como referência a identidade do turista.

Os conflitos entre nativos e turistas estão na origem de toda a discussão sobre o turismo e tem seu cerne na divergência radical de objetivos, uma vez que o turista se entrega a uma atividade de prazer enquanto o nativo trabalha (Robinson, 1999).

A complexidade do fenômeno turístico está nesta justaposição de culturas e identidades, ficando por isso conhecido como "uma indústria da comparação". Na medida em que o turismo manifesta o mundo em um lugar, faz surgir novos lugares para o mundo, muitas vezes à custa de uma descaracterização do local, condição sine qua non que atenderia às exigências do padráo de consumo mundial, uma vez que se constitui num lugar para consumir e, conseqüentemente, numa cultura para ser consumida (Hazin, Oliveira \& Medeiros, 2000). É nesse sentido talvez que os moradores da Ilha do Medo se preocupam em defender o local onde moram embora saibam que não lhes pertence. Afirmam o tempo inteiro que não são donos, que pertence a União, que é monitorado pela Marinha. No entanto, emerge no discurso dos moradores, vez por outra, a expressão "terra de ninguém", que por isso passa a ser de quem habita, de quem cuida, de quem protege.

É interessante perceber que a narrativa dos nativos da Ilha do Medo em relação aos nãonativos é caracterizada pelo perigo trazido pelo desconhecido, "pessoas que não são daqui e que ninguém sabe de onde são", ou seja, pessoas de 
lugar nenhum, o que os transforma facilmente em perigosos e parece colocar os moradores $\mathrm{da}$ Ilha em situação de risco. Um risco eminente causado pelo contato com o Outro que, além de representar perigo no que se refere à violência física, pode transpor a fronteira da violência física para a cultural por representar uma ameaça aos moradores que lutam para proteger o local onde vivem, mantendo intactos os valores culturais.

A discussão sobre o turismo como fator de ruptura da estrutura das sociedades receptoras foi levantada por Jordan (apud Banducci Jr., 2005) ao analisar o processo de implantação do turismo em uma vila norte-americana em New Jersey. Segundo Banducci Jr.:

O autor ressalta que, para os moradores do lugar, o turismo aparece como um fardo que a comunidade deve suportar. Os turistas que afluem para a região no verão, interferem de forma significativa no cotidiano de seus habitantes, acostumados a uma vida pacata e centrada na comunidade. Ainda que seja uma importante fonte de renda, o turismo representa, segundo o autor, a perda da tranqüilidade e da privacidade da população local (Banducci Jr. , 2005, p.28).

Vale ressaltar que o contato repentino entre os estabelecidos e os outsiders esbarra nos ensinamentos da sociedade do "não fale com estranhos", que utiliza esta técnica de desvio e evasão como dispositivo de segurança para os indivíduos. A sociedade ensina-nos a lidar com a alteridade e seus lugares através de estratégias como a antropofágica (nos lugares fágicos), que tenta aniquilar a alteridade ingerindo, assimilando, devorando pessoas para fazê-las idênticas aos que as ingerem ${ }^{10}$; e a antropoêmica,

10. Lembramos que o turismo é um deslocamento coletivo, associado à expansão do Ocidente, que consome outras culturas e lugares. cujo sentido é aniquilar o Outro, impedindo o contato, o diálogo, a interação, através da exclusão (transformando alguns lugares em lugares êmicos) (Bauman, 1998, 2001).

Há aqui uma confrontação entre dois mundos, duas identidades. A nativa, construída sobre as sólidas rochas da Ilha do Medo por um grupo coeso e solidário, que teme ver naufragar seu modo de vida a partir do contato e, mais especificamente, da apropriação que os estranhos farão de um território que eles entendem como sendo deles por ter servido de cais para a construção de um modo de vida sui generis. A outra identidade é a do turista, que está de passagem e por essa razão não se preocupa com o que deixará na Ilha do Medo, do lixo à representação que se construirá dela durante a sua estadia e que pode se prolongar por muito mais tempo.

Em O mal-estar da pós-modernidade, Bauman (1998) apresenta o turista como uma metáfora do herói da contemporaneidade, sujeito que representa o processo de desencaixe espaçotempo (Giddens, 1991) e a fluidez e a mobilidade da modernidade líquida (Bauman, 2001), ao mesmo tempo em que é vítima da "síndrome do turista". O turista seria entâo aquele que se recusa a se fixar em qualquer lugar que seja, vivendo o presente sempre recortado, separado do passado e do futuro, transformando o presente num "presente contínuo".

Assim, a construção da identidade do turista segue a regra do indivíduo da pós-modernidade, cuja identidade é circunstancial, efêmera, descartada e não está mais ancorada a quaisquer processos estruturais mais amplos (Hall, 2005). O deslocamento constante do turista permitiria a este a construção, desconstrução e reconstrução contínua de sua identidade transformada e adaptada a cada nova situação, garantindo o jogo da pós-modernidade onde as regras mudam a cada momento. Para Bauman: “o eixo da estratégia de vida pós-moderna não 
é fazer a identidade deter-se - mas evitar que se fixe. A figura do turista é a epítome dessa evitação" (Bauman, 1998, p. 114).

O turista então realiza "a façanha de não pertencer ao lugar que pode estar visitando; é dele o milagre de estar dentro e fora do lugar ao mesmo tempo. O turista guarda sua distância, e veda a distância de se reduzir à proximidade" (idem). A mobilidade garante o jogo, cujo objetivo maior é estar em movimento e não chegar.

Isto justificaria o tipo de relação estabelecida pelos turistas com seus anfitriōes, definido por Bauman como "relaçôes epidérmicas", portanto, superficiais. Assim, as descreve:

as pessoas do lugar, com que os turistas se deparam, eles literalmente 'tropeçam com' elas acidentalmente, como um efeito colateral do empurrão de ontem, que antes de ontem ainda não era imaginado ou antecipado, e que poderia facilmente ser diferente do que era, e levar o turista para algum outro lugar. A companhia delas tinha nascido de um impulso e de uma vontade que morreram no que se seguiram. É verdade que a companhia é a conseqüência do movimento, mas é uma conseqüência não antecipada: nấo foi parte da transaçáo e não tem nenhum direito sobre a lealdade do viajante (Bauman, 1998, p.115).

Para Bauman, este tipo de relação garantiria o "controle situacional" por parte do turista que pode escolher com que partes do mundo 'interfacear' e quando desligar a conexão. Assim, o turista enxerga o mundo em sua estrutura e suas relações, a partir do seu olhar errante.

Este "controle situacional" a que Bauman se refere, encontra o seu suporte no fato de que o turista opta por estar em movimento, mas pode voltar ao lar e à rotina doméstica quando desejar, e é essa certeza do retorno possível a qualquer momento ao seu mundo estável que dá ao turista o caráter de não pertencer a "lugar nenhum" mesmo quando permanece em algum lugar.

Por essa razão, para Bauman, o turista não transforma e não deseja transformar estes lugares em sua casa nem as relaçóes superficiais, "epidérmicas", em sólidas ou duradouras. Se, por um lado, as relaçôes epidérmicas e superficiais garantem ao turista este controle situacional, por outro, elas geram aquilo que Bauman define como a "síndrome do turista" caracterizada pela perda dos laços com o lugar (geográfico e social) que o tornaria vítima de um dos mal-estares da pós-modernidade.

Ao contrário de Bauman, MacCannel (1992) - cuja preocupação constante é a negatividade que recaiu sobre o turista em grande parte dos estudos sobre o turismo - alega que os turistas têm sido criticados não por deixarem suas casas em buscas de novos lugares, mas por se satisfazerem com experiências superficiais de pessoas e lugares.

Essa superficialidade do turista, porém, é contestada por MacCannel para quem o turista se envergonharia não por ser turista, mas por não sê-lo o suficiente, por náo conseguir ver tudo o que deveria. Assim, ao contrário da superficialidade, o turista quer envolvimento: "todo turista deseja este envolvimento mais profundo com a sociedade e a cultura em algum grau; este é o componente básico de sua motivaçáo para viajar" (MacCannel, 1992, p. 10)

A positivaçáo do turista na teoria de MacCannel se dá também contra a idéia de que a sua presença legitimaria os chamados "pseudoseventos", força motriz da indústria turística. Para o autor, a consciência turística é motivada pelo desejo por experiências autênticas, apesar da dificuldade no reconhecimento de quais experiências seriam de fato autênticas.

Assim, MacCannel (1999) atribui ao turista uma importante função social a cumprir: a reconstrução de uma tradição modificada ou 
perdida. Neste caso, o turismo gera mais do que "encontros turísticos", mas engendra "experiências culturais" marcadas pela alteridade entre culturas, mas também pelo reencontro de um grupo com sua própria tradição, muitas vezes abandonada ou esquecida.

A presença do turista reforça e legitima a tradição (reinventada ou encenada) da comunidade e, mais do que isso, apresentando-se como forasteiro e, portanto, uma ameaça à integridade cultural por atentar contra a consciência comum cristalizada nas tradiçóes e costumes, o turista contribui com a comunidade no fortalecimento dos laços sociais.

$\mathrm{Se}$, por um lado, os nativos alegam que os turistas, "invasores", pertencem a lugar nenhum, o olhar do turista e a sua não-identificação com o lugar termina por transformá-lo em um não-lugar, nos termos de Marc Augé (2004), ou num lugar não-dito, como assim o define Michel de Certeau (2005).

Em sua teoria dos não-lugares, Marc Augé, para quem a supermodernidade é produtora de não-lugares, critica a noção sócio-antropológica de lugar construída pela etnologia a partir de uma compreensão de cultura localizada no tempo e no espaço, e transformada por Mauss (2003) em seus fragmentos num fato social total.

O lugar antropológico, segundo Augé, teria um princípio de sentido para aqueles que o habitam e um princípio de inteligibilidade para quem o observa. Seriam então os lugares de memória de Pierre Nora (1993), "onde aprendemos essencialmente nossa diferença, a imagem do que náo somos mais". Por isso, para os turistas, esses lugares de memórias não existem, os não-lugares que freqüentam não detêm passado nem futuro, enquanto o lugar é sempre identitário, relacional e histórico.

Os não-lugares, em contrapartida aos lugares sociológicos, são lugares de deslocamento, onde os sujeitos que o ocupam o fazem transitoriamente sem que se construa uma identificação com aquele lugar. É assim que, no que se refere ao turista, sua parada ou permanência nesses lugares de passagem o transformam num não-lugar. Conforme Augé, a viagem turística é constitutiva de não-lugares; quem viaja não faz senão passar de um lugar a outro (Augé, 1999, p.145).

Podemos considerar que o turista se desloca em busca de outra realidade, diferente daquela que vivencia em seu cotidiano. Busca, pois, o extraordinário que rompe com a prática cotidiana engendrando um outro modo de olhar as coisas a sua volta. A este novo modo de olhar Urry (2002) chamou de "olhar turístico", que não seria monocausal nem unidimensional $\mathrm{e}$ sofreria variaçôes de acordo com a sociedade, os grupos sociais e o período histórico (Urry, 2002, p. 1). Uma das principais causas da elaboração deste novo olhar seria a relação entre pessoas e culturas.

Ao se referir aos não-lugares, Bauman (2001) afirma que esses espaços interditórios foram desenhados para serem circundados, atravessados, razão pela qual está repleto de passantes, transeuntes. Nos não-lugares, todos devem se sentir como se estivessem em casa, mas ninguém deve comportar-se como tal, especialmente porque estes espaços são engendrados para serem atravessados e deixados para trás o mais rapidamente possível.

Essa idéia nos remete sobre um ângulo aproximado a Michel de Certeau e a sua teoria do espaço praticado. Ao distinguir espaços de lugares Certeau (2005) afirma que o espaço é o efeito produzido pelas operaçóes que o orientam, circunstanciam, temporalizam e o levam a funcionar em unidade polivalente de progresso conflituais ou de proximidade contratuais. Diverso do lugar, o espaço não tem a univocidade nem a estabilidade de um próprio: deste ponto de vista, existem tantos espaços quantas experiências espaciais distintas. A perspectiva é determinada por uma fenomenologia do existir no mundo. Assim, o espaço é um lugar praticado. 
O espaço geométrico é diferenciado do espaço antropológico para o qual o espaço é existencial e a existência espacial (Certeau, 1994, p. 202).

Ainda para Certeau, a definição do espaço praticado enquanto lugar passa pela metáfora da linguagem: "o espaço seria para o lugar o que se torna a palavra quando é falada", pois, apenas quando é falada, é que a palavra ganha e impóe um sentido, torna-se inscrita num contexto que lhe confere sentido. Certos lugares só existem pelas palavras que os evocam, não-lugares são lugares não-ditos que garantem o anonimato daqueles que por eles transitam. Assim, um não-lugar de Marc Auge seria o lugar nãodito ou o lugar não praticado de Certeau.

Ao discorrer sobre o viajante, Certeau caracteriza o seu espaço como o arquétipo do não-lugar, onde nem a identidade, nem a relação, nem a história fazem realmente sentido. Esse movimento do viajante não tem outro fim senão ele mesmo.

Pensando os chamados destinos turísticos como não-lugares, acredito que, se a supermodernidade, como define Augé a atualidade, é rica no surgimento e proliferação de nãolugares, o turismo se torna um dos grandes empreendimentos da contemporaneidade por expandir essa apropriação descompromissada dos indivíduos pelos não-lugares, garantindo deslocamentos de grandes massas de sujeitos tendo este fim por ele mesmo.

Em meio a essa apropriação dos lugares pelos turistas e a constante transformação destes lugares em não-lugares é que emerge o conflito entre turistas e autóctones, pois se estabelece uma preocupação entre integridade e contaminação como demonstrada cada vez que os nativos tratavam do desejo de manutençấo da identidade do grupo, reforçando a construção social do conservadorismo cultural num tempo em que se fala cada vez mais em culturas híbridas, etnicidade reconstruída, o global e o local, fluxos e fronteiras (Hannerz, 1997). Entretanto, é preciso lembrar que o sentimento de uma identidade comum é uma fabricação da experiência compartilhada no interior das fronteiras, sejam elas territoriais, ou culturais.

Assim, o discurso dos nativos se fortalece a partir de concepçóes dicotômicas que se assemelham às relaçóes entre eles mesmos e os "intrusos": tradição versus modernidade, localização versus globalizaçáo, dentro versus fora, hospedeiro versus visitante, integridade versus contaminação.

Todavia, a antropologia contemporânea tem nos alertado sobre os riscos de empobrecimento das análises que se mantêm circunscritas às dicotomias. Há muito mais complexidade entre estes grupos e suas representaçóes internas do que esses esquemas dicotômicos/simplificados poderiam revelar-nos. Não há harmonia nem coesão no que se refere às representaçôes, mas, como nos diz Weber (2004), se "a realidade é um caos, a tarefa do pesquisador é ordená-la". Um estudo minucioso das trajetórias dos nativos da Ilha do Medo em seus depoimentos revelar-nos-ia, talvez, outros interesses e desejos que legitimariam o processo de implantaçáo do turismo na Ilha.

Neste artigo, detive-me a uma análise das representaçôes dos nativos sobre os turistas e, especialmente, da relação que se estabelece entre os autóctones e os planejadores de turismo. A análise sobre o comportamento do turista na contemporaneidade se fundamenta muito mais nas teorias atuais sobre o turismo, numa tentativa incessante de lançar luz sobre a reação dos autóctones numa garantia de uma melhor compreensão da situação que por ora vivenciam.

Numa próxima "exploração", devo transformar este caminho num caminho de mão dupla, navegando pelas representaçóes dos turistas sobre os nativos e buscando desvendar as contradiçóes internas a cada uma dessas representaçôes apresentadas em seu conjunto. Sem perder de vista, claro, que as redes que 
se constroem em torno destas relações e suas dinâmicas, jamais se deixarão apreender pela simplificação das dicotomias ou pela armadilha do discurso do grupo e da representação que se quer coesa, harmônica e hegemônica.

\section{Consideraçóes finais}

Este artigo se compõe de conflitos e tensões estabelecidos no campo e aqui narrados, que resultam da minha experiência como antropóloga junto a uma equipe de profissionais diversos, responsável pelo projeto de implantação do turismo na Ilha do Medo; da representação que se estabelece pelos nativos dos turistas; e da relação que se instaura entre os nativos e a equipe de profissionais que são relacionados pelos ilhéus à prefeitura de Sáo Luís, que sempre agiu com descaso em relação à Ilha do Medo.

Dentre estes, o conflito maior que parece ser o invólucro de todas as outras tensóes é o que se cria entre residentes e turistas pelo fato dos primeiros sentirem-se inseguros ao verem o lugar onde habitam repleto de estranhos cuja origem e destino são desconhecidos.

Ademais, como nos diz Grünewald "o turista é percebido como um 'neonômade' que, apesar de reconhecer fronteiras, sustenta uma consciência desterritorializada" (Grünewald, 2001, p. 31). A situação de nomadismo dos turistas cria entre os anfitriôes (sedentários) o sentimento de risco uma vez que este sentimento está associado ao desconhecimento do Outro. Ser nômade e estar de passagem é estar livre de compromissos com regras locais ou pessoas.

Afora isso, Bauman (2001) nos lembra que a guerra na modernidade líquida não é pela posse do território ou pelo desejo de fixação, mas pelo direito ao fluxo, numa espécie de "vingança do nomadismo" que, com seu poder extraterritorial, dominaria a maioria assentada.
É preciso considerar ainda, no que concerne à Ilha do Medo, o despreparo dos agentes responsáveis pelo processo de implantação do turismo para lidar com os autóctones, motivo da tensão causada entre eles. Prova disso foi o mal-estar gerado por alguns dos profissionais lá presentes que, irritados com a resistência dos moradores, afirmaram que a Ilha do Medo não os pertencia, sugerindo que, se necessário, eles seriam facilmente deslocados de lá.

Por essa razão, os profissionais, especialmente os planejadores do turismo, também ocupam um lugar de fogo cruzado entre turistas e autóctones, uma vez que, exercendo sua função, deixam de ser mediadores e passam a ser vistos como os responsáveis diretos pela implantação do turismo na Ilha.

Um aspecto a ser considerado é que a indústria turística náo deve privilegiar unicamente os turistas, esquecendo que os produtos culturais têm origem em atores sociais com representações próprias sobre os espaços que partilham com aqueles que os visitam. Desta forma, a qualidade de vida das populaçóes e o enriquecimento mútuo entre população e visitantes deveria ser uma preocupação dos modelos turísticos. Nos contatos culturais, está sempre presente a possibilidade de conflito, que não deve ser alimentado pela indústria turística.

No caso da Ilha do Medo, um outro dilema está dado entre o interesse em manter o modo de vida no local e o desejo do crescimento econômico, a busca pelo desenvolvimento e pela melhoria da infra-estrutura no local em aspectos que sáo de responsabilidade do poder público, mas que só aparecem acessíveis aos moradores, no discurso dos profissionais da implantação, via aceitação do turismo.

Isso fica evidente quando refletimos sobre as propostas da SETUR para atrair o desejo da população local pelo turismo. Dentre elas estavam: a garantia de que eles seriam os responsáveis pelo transporte das pessoas de Sáo Luís à 
$90 \mid$ Emilene Leite de Sousa

Ilha do Medo em suas embarcaçôes, cobrando os valores a serem estipulados para isso; a garantia de que eles e seus filhos seriam os guias turísticos por serem os conhecedores de todos os recantos da Ilha, devendo levar os turistas pelos passeios pela trilha ecológica; a garantia de que seriam os únicos a terem permissão para a comercializaçáo de alguns produtos de primeira necessidade; além de terem garantida a coleta de lixo a ser feita sistematicamente em embarcaçôes especiais a serem alugadas pela prefeitura dos próprios pescadores da Ilha. Assim, a população local obteria fontes de renda a serem somadas à agricultura e a pesca.

Ademais, a Ilha do Medo ganharia uma infra-estrutura com posto de primeiros socorros; a implantação de sistemas de captação de energias limpas (eólica- solar); fossas sépticas com biodigestor; poços artesianos; trapiche; centro de apoio ao visitante etc. Também a SETUR prometia a realização de cursos a serem oferecidos para os moradores da Ilha sobre o papel do anfitriáo no turismo.

Devido a estas propostas, percebemos durante a nossa estadia no local que os ilhéus se dividiam entre a aceitação da inclusão da Ilha do Medo no mercado turístico e a não-aceitação. Ficou-se sabendo dias depois que o morador que estivera na SETUR sofreu pressão dos autóctones do local após a saída da equipe no término da "exploração" sendo acusado por ter "oferecido" a Ilha do Medo a SETUR o que tornou ainda mais crítico o mal-estar na Ilha.

Por fim, é importante ressaltar a necessidade da construção, no exercício da escrita etnográfica, de textos mais polifônicos, uma vez que os estudos sobre o turismo, mesmo na antropologia, estão ainda muito centrados no próprio turista. Numa espécie de antropologia de nós, a voz dos autóctones continua inaudível.

É preciso lembrar que os autóctones são agentes importantes neste processo e que este turismo passional tem esperado sempre que eles se adaptem aos turistas e não o contrário, o que caracteriza uma atitude etnocêntrica.

Uma antropologia dos hóspedes ou anfitriôes, numa análise do turismo como fenômeno social, é possível e deve ajudar a compreender a lógica do Outro, do nativo, como nos dizia Malinowski (1978), tarefa maior do antropólogo.

\section{"Invasion" of the Ilha do Medo: the pro- cess of implantation of tourism and the reac- tion by the natives from the island}

abstract This article presents the process of implantation of the communitarian tourism in Ilha do Medo, Maranhão, and the reaction of natives against "the invaders", the way how they define the tourists. It also reports the dialogue between the natives and the planners of tourism sent to the Ilha do Medo. The natives' reaction in relation to the transformation of the Ilha do Medo in a new touristic place in São Luís demonstrates the islanders concern in keeping their local way of life. The representations of natives on tourists are endorsed in dichotomies such as: conservation $\mathrm{x}$ destruction, known $\mathrm{x}$ unknown, inhabitants $\mathrm{x}$ invaders, security $\mathrm{x}$ danger. As it relates the relationship that was settled between natives and tourists, the analysis the of tourism implantation process make us understand the social relations among tourism planners, natives and the ethnographer in his or her field trip.

keywords Tourism. Anthropology. Native of the island. Tourist. Ilha do Medo.

\section{Referências bibliográficas}

AUGÉ, Marc. Não-lugares: introdução a uma antropologia da supermodernidade. $4^{\mathrm{a}}$. ed. Campinas: Papirus, 2004. (Coleção Travessia do Século) O sentido dos Outros: atualidade da antropologia. Petrópolis: Vozes, 1999. 
“INVASÃo” À IlHa do Medo | 9 I

ARAÚJO, Silvana Micele de. Artifício e autenticidade: o turismo como experiência antropológica. In: BANDUCCI JR., Álvaro; BARRETTO, Margarita (Orgs.). Turismo e identidade local: uma visáo antropológica. Campinas, Papirus, 2005, p. 49-63 (Coleção Turismo)

BANDUCCI JR., Álvaro. Turismo e antropologia no Brasil: estudo preliminar. In: BANDUCCI JR., Álvaro; BARRETTO, Margarita (Orgs.). Turismo e identidade local: uma visáo antropológica. Campinas: Papirus, 2005. (Coleção Turismo)

BAUMAN, Zygmunt. O mal-estar da pós-modernidade. Rio de Janeiro: Jorge Zahar Editor, 1998. Modernidade líquida. Rio de Janeiro: Jorge Zahar Editor, 2001.

CERTEAU, Michel de. A invenção do cotidiano: artes de fazer. Petrópolis: Vozes, 2005.

CLIFFORD, James. Authenticity and commoditization in tourism. Annals of Tourism Research, v. 15, p. 371378, 1989.

DAMATTA, Roberto. O ofício do etnólogo: ou como ter um "anthropological blues". In: NUNES, E. (Org.) $A$ aventura sociológica. Rio de Janeiro: Jorge Zahar Editor, 1978, p. 23-35.

DIEGUES, Antonio Carlos. O mito moderno da natureza intocada. São Paulo: Hucitec, 1996.

ELIAS, Norbert; SCOTSON, John L. Os estabelecidos e os outsiders: sociologia das relaçóes de poder a partir de uma pequena comunidade. Rio de Janeiro: Jorge Zahar Editor, 2000.

GIDDENS, Anthony. As conseqüências da modernidade. São Paulo: Editora UNESP, 1991.

GONÇALVES, José Reginaldo Santos. Apresentação. In: CLIFFORD, James. A experiência etnográfica: antropologia e literatura no século XX. Rio de Janeiro: Editora da UFRJ, 2002, p. 7-16.

GRÜNEWALD, Rodrigo de A. Os indios do descobrimento: tradição e turismo. Rio de Janeiro: Contra Capa, 2001.
HALL, Stuart. A identidade cultural na pós-modernidade. $10^{\mathrm{a}}$ ed. Rio de Janeiro: DP\&A, 2005. 102 p.

HANNERZ, Ulf. Fluxos, fronteiras, híbridos: palavraschave da antropologia transnacional. Mana, v. 3, n.1, 1997.

HAZIN, Ana; OLIVEIRA, Cleide; MEDEIROS, Rejane. Turismo e mão-de-obra: entre o real e o ideal. Recife: Fundação Joaquim Nabuco/Universidade Católica de Pernambuco, 2000.

KRIPPENDORF, Jost. Sociologia do turismo: para uma nova compreensão do lazer e das viagens. $3^{\mathrm{a}} \mathrm{ed}$. São Paulo: Aleph, 2001 (Coleção Turismo).

LAPLANTINE, François. A descrição etnográfica. São Paulo: Terceira Margem, 2004.

LÉVI-STRAUSS, Claude. Tristes trópicos. São Paulo: Companhia das Letras, 1996.

MACCANNEL, D. The tourist: a new theory of the leisure class. New York: Shocken, 1992.

MALINOWSKI, Bronislaw. Argonautas do Pacifico Ocidental: um relato do empreendimento e da aventura dos nativos nos arquipélagos da Nova Guiné Melanésia. 2a ed. São Paulo: Abril Cultural, 1978 (Coleção Os Pensadores).

NASH, Dennison. Anthropology of tourism. Kidlington, Oxford, 1996.

NORA, Pierre. Entre Memória e História: a problemática dos lugares. Projeto História. n. 10, São Paulo: PUC, 1993, p. 07-28.

PEREZ, Xerado Pereiro. Patrimonialização e transformação das identidades culturais. In: PORTELA, J.; CASTRO CALDAS, J. (Coords.). Portugal chão. Oeiras: Celta editora, 2003, p. 231-247.

ROBINSON, Mike. Por um turismo consensual. O Correio da UNESCO, p. 22-23, set./out., 1999.

URRY, John. The tourist gaze. London: SAGE Publications, 2002.

WEBER, Max. Weber: Sociologia. 7aa. ed., n. 13. São Paulo: Ática, 2004. (Coleção Grandes Cientistas Sociais)

\section{autor Emilene Leite de Sousa}

Professora da Universidade Federal do Maranhão/UFMA

Mestre em Sociologia/UFPB

Recebido em 30/03/2007

Aceito para publicação em 28/1 1/2007 